Brit. J. Ophthal. (1959) 43, 255.

\title{
OBITUARY
}

\section{PHILIP GEOFFREY DOYNE}

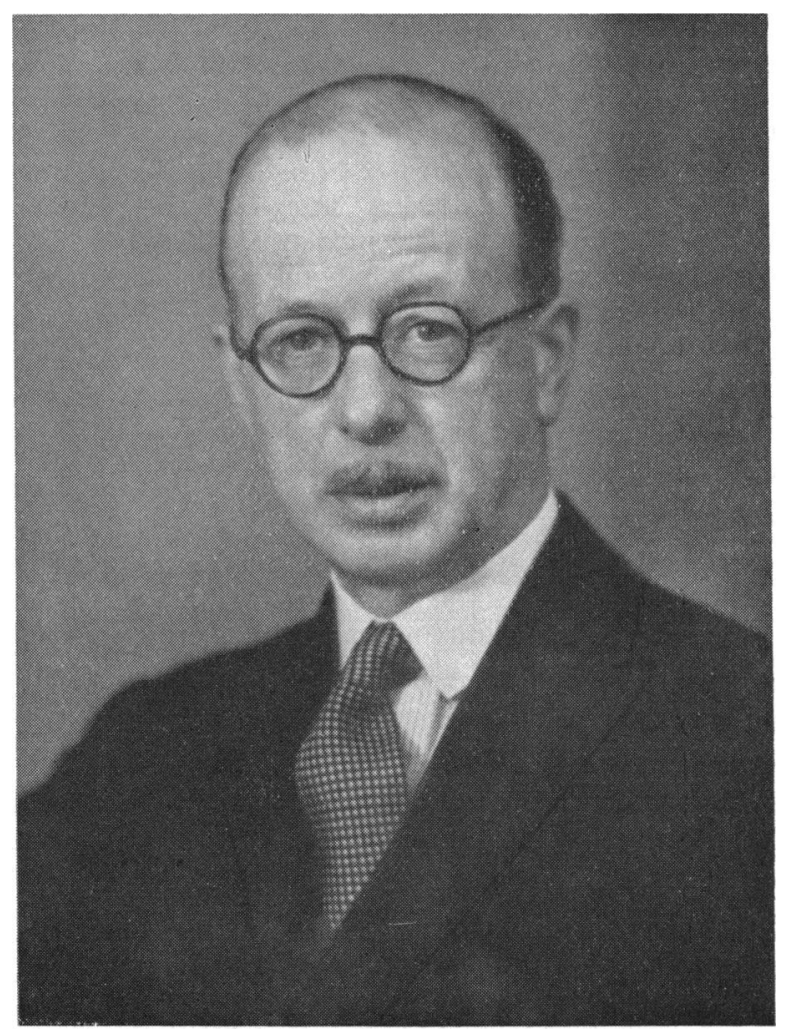

Progressive and harrowing ill health had taken Geoff Doyne from the company of his friends for a number of years. But many, especially those who knew him in London and Oxford, will have been saddened by the news of his death.

Philip Geoffrey Doyne was born in 1886, the elder son of Robert Doyne, whose name is esteemed in ophthalmological circles all over the world. He was educated at Winchester, Trinity College, Oxford, and St. Thomas's Hospital, from which he qualified in 1913 following this by his F.R.C.S. (Eng.) in 1914. He served with the R.A.M.C. in the 1914-18 war and spent three years in Mesopotamia, becoming the Army Eye Specialist in Baghdad. He settled in London after the war and in due time was appointed ophthalmic surgeon to St. Thomas's Hospital and surgeon to the Royal London Ophthalmic Hospital (Moorfields). For a number of years he was ophthalmic surgeon to the Hospital for Sick Children, Great Ormond Street. He was an examiner for the Diploma in Ophthalmology at Oxford for some years before the university discontinued the examination.

He was of retiring nature and wrote and spoke little in medical circles, but was known to his colleagues and patients as a conscientious, kind, and sound ophthalmologist 
whose work and opinion were held in high regard. He became a Vice-President of the O.S.U.K., but a major affection was for the Oxford Congress founded fifty years ago by his father. Of this he was Master in the years immediately after the 1939-45 war and his delightful company there and advice on the Congress Council over the years will be remembered by many of his colleagues in Great Britain and overseas. His modest, gentle charm, his slightly diffident merry wit, and his hospitality endeared him to all who knew him.

He was fond of games, he rowed in his College boat, and with his brother, especially when in later years he lived outside Henley, he kept a keen interest in rowing all his life. But his major athletic interest which brought him international fame was in fencing, for he was twice British Amateur Foils Champion and was in the Olympic team for that weapon. His fairness, skill, and courage brought honour and many demands for service as fencer, judge, and adviser. He kept fit enough to fence regularly till the age of sixty and enjoyed the company of a wide circle of friends.

To his widow, his quiet but stalwart support, and to his daughter, his many friends extend their most real sympathy.

\section{NoAH PINES, 1888-1959}

Many people in Great Britain will be sad to hear of the death of Noah Pines on January 10, 1959. Born in Moscow he spent turbulent years as a student during the recurrent pogroms which occurred in Russia at the time. He qualified in medicine in Kiev in 1911 and when war broke out joined the Russian Army in which he achieved considerable distinction. At the time of the revolution he came to England and there took a medical degree; knowing no English he answered all his papers in Latin. Although practising ophthalmology all his life, he decided at the age of 63 to take out a special academic qualification-and succeeded. Soon after his arrival in England he became a founder member of the consultant staff of the London Jewish Hospital, and was a constant attender and frequent speaker at ophthalmological meetings. His sterling work among the casualties during the bombing of London in the second world war was officially recognized by the Order of St. John of Jerusalem. A careful clinical observer with a sound knowledge of general medicine, he will probably be best remembered for his work on vascular conditions in the fundus, particularly those associated with arteriosclerosis. He leaves a wife and three children, all of whom are doctors.

\section{KeNNETh BLACK}

Mr. Kenneth Black, F.R.C.S., L.D.S., died on January 27, 1959, at the age of 79. He was formerly professor of surgery and lecturer in ophthalmology at King Edward VII Medical College, Singapore, and Surgeon to the General Hospital, Singapore.

\section{CORRIGENDA}

In the article by M. E. Cameron entitled "Congenital Arterio-Venous Aneurysms of the Retina" (Brit. J. Ophthal., 1958, 42, 655):

Page 656, line 10: for "inferior nasal artery", read "superior nasal artery".

Page 661, line 4: for "joining the left superior nasal vein and a left superior nasal artery", read "joining the right superior nasal vein and the right superior nasal artery".

Page 663, Fig. 6, Optic foramina: The labels 'left' and 'right' should be transposed. 